\title{
Peranan Orang Tua dan Sekolah dalam Pengembangan Karakter Anak Didik
}

\author{
Sariwandi Syahroni \\ Program Pasacasarjana \\ STAIN Syekh Abdurrahman Siddik, Bangka-Belitung \\ E-mail: sari_syahroni@gmail.com
}

\begin{abstract}
Abstrak
Artikel ini membahas peran orang tua dan sekolah dalam pengembangan pendidikan karakter. Karakter adalah sifat psikologis, moral, dan tata krama yang dapat membuat seseorang terlihat berbeda dari orang lain. Karakter seseorang terlihat kembali dari keaslian kepribadian, kepribadian yang baik kemudian disebut mulia, dan sebaliknya kepribadian buruk kemudian disebut karakter tercela. Karena kepribadian seseorang tidak langsung berevolusi secara pasif, namun secara aktif menggunakan kapasitasnya untuk menyesuaikan diri terhadap lingkungan. Disiplinkan diri Anda untuk melakukan tindakan yang dilakukan secara konsisten dan terus menerus akan menjadi kebiasaan yang mengarah pada tercapainya keunggulan. Keunggulan yang bisa kita gunakan untuk mencapai tujuan hidup yang menentukan masa depan kita. Dimanapun pendidikan dengan berbagai tingkatan atau strata harus dilibatkan untuk membangun karakter melalui investasi nilai dan memperkuat nilai karakter dengan cara mengajar dan mendidiknya kepada siswa kita di keluarga (orang tua) dan sekolah: sekolah umum atau madrasah. Tampaknya peran orang tua dan sekolah itu sendiri membutuhkan kerjasama sinergis untuk mengembangkan karakter siswa.
\end{abstract}

Kata Kunci: Peran, Pengembangan Karakter, Orang Tua, Sekolah

Di era global, dimana berbagai dimensi kehidupan seakan terus dinamis dan berkembang secara pesat, berdampak terhadap banyaknya perubahan-perubahan yang dialami setiap insan, masyarakat, pemerintah maupun negara di segala bidang. Perubahan itu sendiri merupakan suatu tantangan dan sekaligus sebagai suatu paradigma baru untuk selektif menghadapi perubahan dunia yang sangat cepat dan pesat bagi anak didik sebagai generasi muda masa depan bangsa. Oleh karena itu, diperlukan adanya suatu strategi sebagai penyeimbang terhadap perkembangan zaman yang serba modern dan canggih, serta serba instan tersebut.

Untuk mewujudkan upaya-upaya dan harapan tersebut, agaknya satu-satunya harapan terdepan terletak pada dun dapat menciptakan anak-anaknya bagai generasi masa depan, yang berkarakter kuat dan memiliki suatu generasi berintegritas yang diperlukan negeri ini. Sebuah keinginan yang boleh jadi terdengar berlebihan, meski sesungguhnya amat wajar dan realistis mengingat pendidikan memang suatu tumpuan solusi dari sekian banyak persoalan sumber daya manusia (human-resources) dan problema kemasyarakatan dalam setiap zamannya yang selalu dinamis. Pendidikan pada hakekatnya adalah menuju suatu proses perubahan perilaku dan sebagai kebutuhan sosial (social-needs) masyarakat. 


\section{Sariwandi Syahroni}

Peranan Orang Tua dan Sekolah

dalam Pengembangan Karakter Anak Didik

Dari banyak persoalan berbangsa, sejak dari persoalan perilaku: korupsi, narkoba, minuman keras dan oplosan, eksploitasi sumber daya alam, pergaulan bebas, rendahnya sopan santun, dan rasa hormat antara muda dan lebih tua, malas malasan, kebut-kebutan dijalan raya, melanggar rambu lalu lintas, meningkatnya perilaku kriminal, konflik sosial dan lain-lain, yang sekaligus merupakan indikator-indikator krusial yang menunjukkan telah terjadinya degradasi akhlak, moral dan etika social (Idi, 2015: 189). Anak didik dan generasi muda merupakan harapan keluarga/orang tua, masyarakat dan bangsa, karena berbagai persoalan berbangsa itu hanya pada mereka diharapkan dapat menjadi tumpuan solusinya di masa depan.

Pendidikan sebagai benteng untuk menciptakan situasi yang dinamis belum optimal bisa mentransferkan eksisnya sebagai landasan untuk merubah dan membangun karakter bangsa. Berbagai upaya perubahan kebijakan pendidikan nasional agaknya belum bisa memberi wajah perubahan positip sepenuhnya yang berpengharapan bagi bangsa ini. Salah satu masalah utama dan klasik sebenarnya adalah masalah dikotominya suatu lembaga pendidikan, dua idealisme yang tidak bisa menyatukan kekuatan untuk bergotong royong mengembangkan pendidikan secara nasional. Majunya suatu negara yakni apabila segala aspek kehidupan berbangsa agaknya bisa menyatukan pandangan, pola pendidikan yang dinamis demi kemashalatan umat, pendidikan yang baik adalah pendidikan yang jauh dari unsur politik praktis yang berlebihan.

Pendidikan sebagai cabang dari etika sosial lebih fokus mengkaji kewajiban dan norma-norma dalam proses pendidikan, yakni terutama seorang dalam suatu masyarakat negara (memiliki sistem pendidikan tertentu) berinteraksi secara edukatif dengan individu (terlibat dalam proses pendidikan) dan kelompok lain (seperti orang tua dan masyarakat). Sekedar mengingatkan kembali di sini pentingnya memahami mengenai arti moral dan etika. Moral merupakan aturan-aturan normatif (dalam Islam dinamakan akhlak) yang berlaku dalam suatu masyarakat tertentu yang terbatas oleh ruang dan waktu (Idi, 2006: 19).

Pendidikan karakter adalah pilar integrasi ke dalam setiap pembelajaran di sekolah. Demikian dengan UU nomor 20 tahun 2003 tentang Sisdiknas yang mengamanatkan pendidikan berkarakter. Menyadari begitu besar peran pendidikan karakter di sekolah dan madrasah berupaya menanamkan dan menumbuh kembangkan pendidikan karakter yang kuat dengan memberikan keleluasaan bagi peserta didik untuk berani mengambil inisiatif dengan tetap menekankan rasa tanggung jawab. Begitu juga halnya, peran keluarga/orang tua sesungguhnya paling awal dan terdepan dalam mendukung pendidikan karakter di sekolah dan madrasah agar dapat dikembangkan sedemikan rupa.

Untuk mewujudkan target yang akan dicapai maka perlu suatu kesadaran akan pembentukan karakter yang dapat berpengaruh terhadap setiap aspek kehidupan dalam 
masyarakat, keharmonisan di lingkungan sekolah dan keluarga, keamanan, terpadunya nilai-nilai sosial. Secara garis besar, karakter dapat dikatakan juga akhlak. Akhlak dibagi menjadi dua bagian, yaitu akhlak mahmudah (karakter baik) seperti berbuat adil, jujur, sabar, pemaaf, dermawan, amanah dan sebagainya. Sedangkan akhlak mazmumah (karakter buruk) seperti dzalim, dusta, pemarah, pendendam, kikir, sombong, sentiment, tidak bertanggung jawab dan sebagainya. Rasulullah Saw bersabda: "Sesungguhnya hamba yang paling dicintai Allah ialah yang paling baik akhlaknya (karakternya)".

Dari permasalahan di atas merupakan sebuah realitas-sosial yang mana sangat berpengaruh terhadap tingkah laku (karakter) anak didik. Pengaruh karakter bisa dipandang melalui kekuatan emosi seseorang yang bisa lebih kuat daripada kekuatan logikanya. Itu karena otak logika berfikir kalah cepat dengan otak emosi. Yang dimaksud dengan otak emosi adalah bagian otak disebut amigdala, yaitu bagian yang berproses memberikan respon berupa tindakan emosional.

Dari permasalahan di atas jelas sekali belum seluruh sekolah menjadi tempat yang nyaman dan menginspirasi bagi siswa, guru, dan tenaga kependidikan. Pembiasaan sikap dan perilaku positif di keluarga dan sekolah agaknya belum sepenuhnya menjadi perhatian sebagai suatu sistem dari proses belajar daam mendukung iklim pengembangan pendidikan karakter. Karenanya, proses pengembangan pendidikan karakter diperlukan peranan kolektif dari berbagai elemen masyarakat, terkhusus peranan dari orang tua/keluarga dan institusi pendidikan: sekolah dan madrasah.

\section{Hakekat dan Urgensi Pendidkan Karakter}

Seperti diketahui bahwa karakter berasal dari bahasa Yunani "karasso" yang berarti "to mark" yaitu menandai atau mengukir, yang memfokuskan bagaimana mengaplikasikan nilai kebaikan dalam bentuk tindakan atau tingkah laku. Jadi istilah karakter erat kaitannya dengan personalitas seseorang. Pengertian karakter adalah sifat sifat kejiwaan, akhlak, dan budi pekerti yang dapat membuat seseorang terlihat berbeda dari orang lain. Berkarakter dapat diartikan memiliki watak dan juga kepribadian.

Bagaimana posisi pendididkan karakter dalam konteks pendidikan nasional? Keterkaitan dengan pengembangan pendidikan karakter itu sendiri dalam pendidikan nasional, yakni sebagai upaya pembaharuan sistem pendidikan nasional yang telah ditetapkan visi, misi, dan strategi dalam pelaksanaan pendidikan nasional. Visi pendidikan nasional itu sendiri adalah : "Terwujudnya sistem pendidikan sebagai pranata sosial yang kuat dan berwibawa untuk memberdayakan warga negara Indonesia, berkembang menjadi manusia yang berkualitas sehingga mampu dan proaktif menjawab tantangan zaman yang selalu berubah (Idi, 2016: 162)."

Dengan visi pendidikan nasional tersebut, pendidikan nasional memiliki beberapa misi utama sebagai berikut : (1) Mengupayakan perluasan dan pemerataan kesempatan memperoleh pendidikan yang bermutu bagi seluruh rakyat Indonesia; 92) 


\section{Sariwandi Syahroni}

Peranan Orang Tua dan Sekolah

dalam Pengembangan Karakter Anak Didik

Membantu dan memfasilitasi pengembangan potensi anak bangsa secara utuh sejak usia dini sampai akhir hayat dalam rangka mewujudkan masyarakat belajar; (3) Meningkatkan kesiapan masukan dan kualitas proses pendidikan untuk mengoptimalkan pembentukan kepribadian yang bermoral; (4) Meningkatkan keprofesionalan dan akuntabilitas lembaga pendidikan sebagai pusat pembudayaan ilmu pengetahuan, ketrampilan pengalaman, sikap, dan nilai berdasarkan standar nasional dan global; dan (5) Memberdayakan peran serta masyarakat dalam penyelenggaraan pendidikan berdasarkan prinsip otonomi dalam konteks Negara Kesatuan Republik Indonesia (Idi, 2011: 162).

Jelas bahwa tujuan pendidikan karakter di setiap sekolah lebih jauh diharapkan mampu merealisasikan secara optimal, sehingga visi, misi serta tujuan pendidikan nasional dapat terealisasikan dengan efektif dengan turut andil serta melibatkan sejumlah elemen/ komponen bangsa secara aktif dalam penyelenggaraan pendidikan. Menurut Undang-Undang Nomor 20/2003 tentang keberadaan Sistem Pendidikan Nasional berfungsi mengembangkan kemampuan dan membentuk watak serta peradaban bangsa yang bermartabat dalam rangka mencerdaskan kehidupan bangsa, bertujuan berkembangnya potensi peserta didik menjadi manusia yang bertakwa kepada Tuhan Yang Maha Esa, berakhlak mulia, sehat, berilmu, cakap, kreatif, mandiri dan menjadi warga negara yang demokratis dan bertanggungjawab. Kurikulum 2013 dipersiapkan untuk mencetak generasi yang siap menghadapi beragam tantangan globalisasi dan kecanggihan teknologi di masa depan. Kurikulum 2013 juga bertujuan melahirkan generasi emas yang memiliki kompetentsi spiritual, sosial, pengetahuan dan ketrampilan secara seimbang.

Pembelajaran di sekolah karenanya diharapkan bermanfaat sebagai bekal kehidupan siswa pada masa kini dan masa datang. Pembelajaran yang bersifat content oriented yaitu mengarahkan siswa pada penguasaan materi pembelajaran dengan hanya sekedar mengetahui berbagai fakta yang lepas-lepas, perlu dimodifikasi lebih menjadi berorientasi kepada kehidupan siswa pada zamannya. Siswa peru diperkenalkan dengan berbagai fenomena kehidupan termasuk dengan pekerjaan sebagai bekal untuk kehidupan mereka. Hal ini sesuai dengan prinsip kurikulum tingkat satuan pendidikan yang dikembangkan dengan berdasarkan prinsip berpusat pada potensi, perkembangan, kebutuhan, dan kepentingan siswa dan lingkungannya. Kurikulum dikembangkan berdasarkan prinsip-prinsip bahwa siswa memiliki posisi sentral untuk mengembangkan kompetensinya agar menjadi manusia yang beriman dan bertakwa kepada Allah SWT kepada Tuhan Yang Maha Esa, berakhlak mulia (berkarakter), sehat, berilmu, cakap, kreatif, mandiri, dan menjadi warga negara yang demokratis serta bertanggung jawab (Sumiati, 2007: 179).

Sebagai mana diketahui bahwa dalam sejarah perkembangan peradaban manusia, bukanlah taken for granted, tetapi jauh sebelumnya telah mengalami suatu proses yang panjang yakni melalui "belajar", "pendidikan", dan "pengalaman" 
tersendiri berdasarkan zamannya. Mereka mungkin tidak sekolah secara "formal" di sekolah, tetapi mereka belajar dari pengalaman. Proses belajar dan pendidikan yang dialami mereka dalam zaman yang berbeda tersebut telah menjadikan manusia mampu memenuhi kebutuhan, menjalani kehidupan hingga memasuki zaman peradaban seperti sekarang ini (Idi, 2011: 59).

Nabi Muhammad Saw. sebagai manusia sempurna yang pernah hidup dimuka bumi telah memberikan contoh keteladanan bagaimana membangun sebuah karakter bangsa dan mempengaruhi dunia. Sehingga Michael H. Hart penulis Buku 100 Tokoh Berpengaruh di dunia menempatkan Nabi Muhammad Saw. sebagai manusia paling berpengaruh sepanjang sejarah kemanusiaan, karena mampu merubah sebuah wajah karakter masyarakat dari realitas masyarakat yang sangat tidak beradab, suka menyembah patung, suatu produk manusia yang disembahnya sendiri, suka berjudi, suka membunuh anak perempuannya karena dianggap melemahkan citra diri keluarga besar (suku), memberikan penghargaan atas wanita dengan cara yang sangat murah dan keji, memperjualbelikan manusia dengan sistem perbudakan menjadi beradab dan bermoral. Semua realitas itu kemudian diubah dengan cara yang sangat indah dan cerdas melalui keteladanan dan dibangun karakter masyarakatnya, kemudian mampu mempengaruhi karakter bangsanya sehingga dapat diakui dalam sebuah kawasan Jazirah Arabiyah bahkan mampu mengubah sejarah perjalanan dunia (Saleh, 2012: 1-2). Jadi, pendidikan karakter memiliki peranan strategis dalam membentuk insan cendekia sebagai generasi masa depan bangsa. Setiap bangsa yang bercita-cita akan maju (developed country) mestilah mempersiapkan generasinya yang berkarakter, berakhlak mulia, yang hanya /orang tua terjadi dan terwujud apabila ada kesadaran bersama dan kolektif dari semua pihak, antara lain: keluarga/orang tua dan sekolah/madrasah.

\section{Orang Tua, Sekolah, dan Pendidikan Karakter}

Pentingnya prestasi belajar dalam setiap proses pembelajaran disekolah adalah sebagai penunjang motivasi belajar peserta didik. Dalam prestasi belajar terdapat sejumlah proses motivasi yang terlibat di dalamnya. Motivasi dibagi menjadi dua perbedaan yaitu motivasi intrinsik dan motivasi ekstrinsik. Dalam konteks proses mewujudkan anak didik yang berakhlakul karimah dan berkarakter, pendidikan Islam sesungguhnya memiliki peranan strategis bahkan terdepan. Karenanya akan dijelaskan tentang implementasi pendidikan Islam dalam berbagai bentuknya dalam membentuk anak didik yang berkarakter dan berakhlak yang pada akhirnya mereka dapat memperkuat karakter bangsa, sebagaimana diharapkan Pancasila dan UUD 1945. Intinya, karakter anak Muslim Indonesia yang diharapkan akan terbentuk dengan pentingnya memerhatikan peran strategis beragam institusi pendidikan Islam, seperti pendidikan madrasah, pesantren, dan PAI di sekolah umum (Idi, 2016: 63).

Motivasi intrinsik (intrinsic motivation) didasarkan pada faktor-faktor internal seperti determinasi diri, rasa ingin tahu, tantangan dan usaha. Motivasi ekstrinsik 


\section{Sariwandi Syahroni}

Peranan Orang Tua dan Sekolah

dalam Pengembangan Karakter Anak Didik

(extrinsic motivation) melibatkan insentif eksternal seperti penghargaan dan hukuman (Santrock, tt: 148). Kedua faktor motivasi tersebut saling berkaitan antara satu dengan yang lainnya, karena manusia memliki rasa ingin tahu yang tinggi dan ingin memperoleh pengakuan di lingkungannya. Memotivasi anak didik diharapkan bisa tumbuh terhadap kebiasaan belajar yang baik. Semestinya yang harus diupayakan adalah bagaimana anak mampu menumbuhkan motivasi intern, yaitu yang datang dalam dirinya sendiri, yang muncul dari kesadarannya sendiri (Istadi, tt: 90).

Dalam setiap proses pembelajaran agaknya perlu membentuk kepribadian yang tangguh dan unggul dari berbagai potensi untuk mewujudkan insan mulia. Karakter seseorang dilihat kembali dari asal kepribadiannya, berkepribadian yang baik maka disebut berakhlak mulia, dan sebaliknya berkepribadian yang buruk maka disebut akhlak tercela. Karena kepribadian seseorang tidak secara langsung berkembang secara pasif, tetapi secara aktif untuk mempergunakan kapasitanya untuk menyesuaikan diri dengan lingkungan. Syarat penting dalam upaya pengembangan diri adalah kemampuannya untuk membangun semangat dan motivasi diri dalam mengembangkan segala potensi yang dimilikinya dalam menggapai segala tujuan dan cita-cita yang diinginkannya. Namun sering kali motivasi selalu bergerak dinamis, kadang diri kita hidup dalam motivasi tinggi namun terkadang juga turun bahkan hilang motivasi diri (Saleh, 2012: 73).

Adapun pada diri seorang (anak didik) terdapat beragam motivasi yang membagi motivasi seseorang yang setidaknya ada tiga macam yang berdasarkan kebutuhan (need) yang dimiliki setiap individu dalam mengelola potensi yang dimilikinya. Macam-macam motivasi tersebut, antara lain : (1) Motivasi Prestasi (Need of Achivement, disingkat dengan N-Ach). Motivasi prestasi adalah kebutuhan seseorang akan prestasi yang merupakan dorongan untuk mengungguli, berprestasi sehubungan dengan perangkat standar, bergulat untuk sukses; (2) Motivasi Afiliasi (Need of Affiliation, disingkat dengan N-Aff). Kebutuhan akan afiliasi adalah hasrat untuk menjalin hubungan antar pribadi yang ra,ah dan akrab. Indivindu merefleksikan keinginan untuk memiliki hubungan yang erat, kooperatif, dan penuh sikap persahabatan dengan pihak lain. Individu yang mempunyai kebutuhan afiliasi yang tinggi umumnya berhasil dalam berbagai hal, apakah belajar atau bekerja yang memerlukan interaksi sosial yang tinggi; dan (3) Motivasi Kekuasaan (Need of Power, disingkat dengan N-Pow). Kebutuhan akan kekuasaan adalah kebutuhan untuk membuat orang lain beprilaku dalam suatu cara di mana orang-orang itu tanpa dipaksa tidak akan berprilaku demikian atau suatu bentuk ekspresi dari individu untuk mengendalikan dan mempengaruhi orang lain (Saleh, 2012: 76-78).

Keterkaitan dengan konsep pendidikan Islam misalnya bahwa dalam Kitab Suci Al Qur'an sebagai sumber motivasi yang berupaya agar seorang untuk berlomba-lomba dalam melakukan shadaqah jariyah (Q.S. al-Baqarah: 261). Ilmu pengetahuan yang bermanfaat, mungkin ini secara lebih khusus menjadi keistimewaan para alim ulama, 
ilmuwan, cendekiawan, kaum intelektual, dan orang-orang yang pintar yang membagikan wawasan ilmu mereka kepada orang lain. Jika disampaikan kepada orang yang membutuhkannya, sebab ketika maut datang, boleh jadi ilmu tersebut yang akan menerangkan perjalanan panjang menunju Tuhan (Zaprulkhan, tt: 15).

Kepribadian bukanlah sesuatu yang dapat dikenakan ataupun ditanggalkan sebagaimana orang mengenakan pakaian ataupun mengikuti gaya mode tertentu. Kepribadian adalah tentang diri pribadi secara keseluruhan, kepribadian adalah sesuatu yang unik pada diri masing-masing individu. Kepribadian adalah organisasi dinamis dalam individu sebagai sistem psikofisik yang menentukan caranya yang khas dalam menyesuaikan diri terhadap lingkungan. Organisasi dinamis dijelaskan menekankan kenyataan bahwa kepribadian itu selalu berkembang dan berubah walaupun dalam pada itu ada organisasi sistem yang mengikat dan menghubungkan berbagai komponen dari kepribadian. Istilah psikofisik menunjukkan bahwa kepribadian bukan hanya eksklusif (semata-mata) mental, dan bukan pula semata-mata neural (Hutagalung, tt: 1-2).

Bertitik tolak dari teori kepribadian seorang muslim, kepribadian tersebut dibagi menjadi dua macam yaitu: (1) Kepribadian kemanusiaan (basyariah), dan (2) Kepribadian kewahyuan (samawi). Selanjutnya, kepribadian kemanusiaan dibagi kepada dua bagian yaitu: pertama, kepribadian individu yang meliputi ciri khas seseorang dalam bentuk sikap dan tingkah laku serta intelektual yang dimiliki masingmasing secara khas sehingga ia berbeda dengan orang lain. Menurut pandangan Islam memang manusia mempunyai dan memiliki potensi psikis. Firman Allah Swt, artinya: "Perhatikanlah mereka bagaimana kami lebihkan mereka sebagian atas sebagian". (Q.S. Bani Israil: 122). Kedua, kepribadian ummah yang meliputi ciri khas kepribadian muslim sebagai suatu ummah (bangsa/negara) muslim yang meliputi sikap dan tingkah laku ummah muslim yang berbeda dengan ummah lainnya, mempunyai ciri khas kelompok dan memiliki kemampuan untuk mempertahankan identitas tersebut dari pengaruh luar, baik ideologi maupun lainnya yang dapat memberi dampak negatif. Firman Allah SWT yang artinya: "Kami jadikan kamu bersuku-suku dan berbangsabangsa saling kenal mengenal....”. (Q.S. Al Hujurat: 30).

Kepribadian samawi (kewahyuan) yaitu corak kepribadian yang dibentuk melalui petunjuk wahyu dalam kitab suci al Qur'an, yang antara lain difirmankan Allah Swt sebagai berikut yang artinya: "Dan bahwa (yang kami perintahkan) ini adalah jalanku yang lurus, maka ikutilah dia, dan janganlah kamu mengikuti jalan-jalan (yang lain) karena jalan-jalan itu mencerai-beraikan kamu dari jalannya; yang demikian itu diperintahkan Allah kepadamu agar kamu bertaqwa (Ramayulis, 2008: 112-113).”

Baik buruknya seseorang hanya terletak pada perangainya (watak), al Qur'an telah menjelaskan dalam surah ar-Rad: 11 yang tertulis : Sesungguhnya Allah tidak merobah Keadaan sesuatu kaum sehingga mereka merobah keadaan yang ada pada diri mereka sendiri. dan apabila Allah menghendaki keburukan terhadap sesuatu kaum, 


\section{Sariwandi Syahroni}

Peranan Orang Tua dan Sekolah

dalam Pengembangan Karakter Anak Didik

Maka tak ada yang dapat menolaknya; dan sekali-kali tak ada pelindung bagi mereka selain Dia." (Qurtuby, 2014: 250).

Dalam proses pembentukan atau pengembangan karakter, suatu faktor yang perlu diperhatikan juga adalah bertalian dengan disiplin. Disiplin berasal dari bahasa latin Discere yang berarti belajar. Dari kata ini timbul kata Disciplina yang berarti pengajaran atau pelatihan. Dan sekarang kata disiplin mengalami perkembangan makna dalam beberapa pengertian. Pertama, sebagai kepatuhan terhadap peratuaran (hukum) atau tunduk pada pengawasan, dan pengendalian; Kedua, disiplin sebagai latihan yang bertujuan mengembangkan diri agar dapat berperilaku tertib; dan Ketiga, kedisiplinan guru diartikan sebagai sikap mental yang mengandung kerelaan mematuhi semua ketentuan, peraturan dan norma yang berlaku dalam menunaikan tugas dan taggung jawab; dan Keempat, kedisiplinan guru dan staf pegawai diartikan sebagai sikap mental yang mengandung kerelaan mematuhi semua ketentuan, peraturan dan norma yang berlaku dalam menunaikan tugas dan taggung jawab terhadap pendidikan anak didiknya (Kemendikbud, 2016).

Disiplin diri merupakan suatu siklus kebiasaan yang anak didik atau seorang lakukan secara berulang-ulang dan terus-menerus secara berkesinambungan sehingga menjadi suatu hal yang bisa kita lakukan. Disiplin diri dalam melakukan suatu tindakan yang dilakukan secara konsisten dan berkesinambungan akan menjadi suatu kebiasaan yang mengarah pada tercapainya keunggulan. Keunggulan membuat kita memiliki kelebihan yang dapat kita gunakan untuk meraih tujuan hidup yang menentukan masa depan kita. Sikap disiplin dapat mengantarkan seseorang pada jalan kesuksesan, karena orang yang berdisiplin akan bersikap teguh dalam menjalani niat dan cita-cita yang ingin diraihnya. Disiplin mampu menjaga agar setiap tindakan yang dilakukan tetap berada pada jalan menuju tujuan akhir yang ingin dicapai, bahkan mampu menjaga tujuan akhir itu sendiri. Kedisiplinan akan terbangun dengan niat yang kuat, motivasi yang utuh dan sungguh-sungguh, serta kesadaran akan alasan dari penetapan tujuan akhir yang ingin dicapai. Sementara ketidaksiplinan akan menjadikan jalan menuju tujuan akhir semakin jauh dan berprilaku karena sikap yang tidak konsisten, bahkan dapat mendatangkan malapetaka bagi dirinya (Saleh, 2012: 297-298).

Keberadaan seorang anak didik yang berkarakter sangan diperlukan kedepan, dimana eksistensi pendidikan diyakini merupakan salah satu agen perubahan sosial (the agent of social-change). Pada satu segi pendidikan sebagai suatu variabel modernisasi atau pembangunan dimana tanpa pendidikan yang memadai, akan sulit bagi anakan didik dan masyarakat manapun untuk mencapai kemajuan. Karena itu banyak ahli pendidikan yang berpandangan bahwa " pendidikan merupakan kunci yang membuka pintu modernisasi”. Tetapi pada segi lain, pendidikan sering dianggap sebagai objek modernisasi atau pembangunan. Dalam konteks ini, pendidikan dinegara-negara yang telah menjalankan progam modernisasi pada umumnya dipandang masih terbelakang 
dalam berbagai hal, karena itu sulit diharapkan bisa memenuhi dan mendukung progam pembangunan.

Ada hal-hal yang harus kita perhatikan bahwa pendidikan untuk perbaikan hidup, sesuai dengan perkembangan zaman dalam suatu masyarakat. Menekankan pada perkembangan dan kemajuan keilmuan, faktor-faktor tersebut diantarannya sebagai berikut: (1) Pendidikan bukan semata-mata untuk belajar tanpa ada sasaran dan arah atau juga tujuan akhir. Pendidikan adalah human investment atau bahkan juga social investment. Artinya, pendidikan itu merupakan investasi, bukan semata-mata penghabisan dana; dan (2) Diperlukan adanya perbaikan sumber daya manusia (humanresources) dan sekaligus perbaikan hasil yang diperoleh setelah selesai (Azizy, tt: 8182).

Oleh karena itu, adalah suatu kewajaran apabila persoalan pendidikan karakter diletakkan pilar integrasi ke dalam setiap pembelajaran di sekolah. Demikian pula halnya dengan UU Nomor 20/ 2003 tentang Sisdiknas yang mengamanatkan pendidikan berkarakter. Menyadari begitu besar peran pendidikan karakter di sekolah brupaya menanamkan dan menumbuh kembangkan pendidikan karakter yang kuat dengan memberikan keleluasaan bagi peserta didik untuk berani mengambil inisiatif dengan tetap menekankan rasa tanggung jawab.

Disatu sisi anak didik dituntut untk mengoptimalkan prestasi akademis, di siis lain, persoalan pendidikan dan pengembangan karakter juga merupakan tujuan pokok dalam proses pembelajaran di sekolah. Anak-anak perlu dibimbing menjadi sesdorang yang mementingkan disiplin, jujur, mandiri, taat beribadah, hormat dan patuh pada orang tua, bertanggung jawab, berbudaya bersih, senang membaca, berkomunikasi santun, dan mencintai al Qur'an (Prolog, tt: 76). Sangat mungkin sekali jika diterapkan dengan penuh rasa niat yang kuat dan ikhlas (sukarela), bersemangat (motivasi) keinginan dan cita-cita anak didik kita akan terwujud, dan memperoleh kebahagian dunia akhirat.

Strategi utama melalui pembiasaan dalam kehidupan sehari-hari di sekolah dan di rumah. Pembiasaan di sekolah, setara dengan empat jam pelajaran per hari dikemas dalam beberapa kegiatan. Sedangkan pembiasaan dirumah dilakukan oleh orang tua melalui panduan Buku Penghubung. Oleh karena itu pada jam pertama pelajaran, sekolah rutin menjalankan program Bina Karakter. Sekitar 20 menit guru memberi nasihat, taushiyah singkat, mendoakan kawan yang sakit sebagai wujud empati kepada sesama, mendiskusikan mengapa masih ada yang terlambat shalat atau lupa mengerjakan tugas, dilanjutkan bersama-sama menghitung infak yang didapat. Dari sekian butir akhlak yang dikembangkan program Bina Karakter, ada satu yang mendapat penekanan khusus yaitu soal kejujuran. Kejujuran harus digenggam teguh di manapun dan kapanpun, karena keberhasilan bila diraih tanpa kejujuran pada hakikatnya adalah kegagalan. 


\section{Sariwandi Syahroni}

Peranan Orang Tua dan Sekolah

dalam Pengembangan Karakter Anak Didik

Selain pembinaan disiplin dilingkungan sekolah, perlu juga pendidikan karakter di lingkungan keluarga, sebagai insitusi pendidikan pertama dan utama. Jika dalam keluarga sudah ditanamkan ketaatan (disiplin) beribadah, tanggung jawab bersama dalam keluarga, kerjasama, sikap bersedia menerima nasehat, bimbingan-bimbingan dalam penentuan sikap individu-individu keluarga dalam urusan hidup. Firman Allah Swt. "Sembahlah Allah dan janganlah kamu mempersekutukan-Nya dengan sesuatupun. dan berbuat baiklah kepada dua orang ibu-bapa, karib-kerabat...." (An Nisaa' ayat 36)

Bimbingan dan kepimpinan yang baik dari orang tua/keluarga muslim harus didasarkan di atas prinsip-prinsip ajaran akhlak Islam, dan yang terpenting ialah prinsip percaya kepada nilai-nilai rohaniah sebagai nilai-nilai insaniah yang tinggi, seperti nilainilai kerjasama, saling membantu dan berpadu antara yang kuat dengan yang lemah. Itulah nilai-nilai yang mengajak orang-orang yang kuat kepada tingkah laku yang positif terhadap orang-orang yang lemah (Albahi, tt: 124). Baik pendidikan formal di sekolah maupun pendidikan informal dikeluarga terdapat beberapa hal yang harus diperhatikan dalam upaya memunculkan sikap disiplin anak-didik. Yakni perlunya memiliki kompetensi sikap sebagai berikut: (1) Kejelasan tujuan yang akan diraih. Semakin jelas sebuah tujuan maka akan mampu mengarahkan pada sebuah sikap yang harus terus secara konsisten dibangun walau banyak rintangan yang muncul dalam perjalanan itu; (2) Memiliki niat yang kuat untuk mencapai tujuan. Niat atau dorongan hati akan menjadikan kita terus melakukan apa yang kita yakini dalam niat itu. Dorongan hati untuk mengejar impian itulah yang akan dengan sendirinya mendisiplinkan diri kita, agar terus berupaya menapaki jalan menuju impian itu; (3) Penetapan skala prioritas.Seseorang yang berkeinginan kuat untuk mencapai impian, maka harus memilih sebuah sikap secara selektif dan tidak sembarangan mempergunakan waktunya; (4) Tekun dan sabar dalam menapaki jalan sukses yang diyakini. Ketekunan dan kesabaran akan membuahkan hasil yang gemilang, karena ketekunan akan membuat seseorang bersedia untuk terus belajar dari sebuah kesalahan dan kegagalan. Beragam masalah yang menghadang akan dinilai sebagai sebuah cara untuk meningkatkan kompetensi dan kemampuan dalam menggapai mimpi yang diinginkannya. Demikian firman Allah Swt: "Jadikanlah sabar dan shalat sebagai penolongmu” (Saleh, 2012: 300-301).

Dalam keluarga muslim, ketika anak-anak berusia dini, mereka hidup dalam pengasuhan kedua orang tuanya. Begitu pula ketika mereka berada pada usia belajar. Orang tua dan pendidik mesti mempunyai suatu metode untuk memperbaiki, meluruskan hal-hal yang keliru, mengarahkan sikap dan perilaku mereka. Dengan demikian mereka tumbuh dan berkembang berdasarkan pedoman-pedoman Islam yang sempurna dan etika sosial yang luhur.bukhari dan Muslim meriwayatkan suatu hadis berikut ini :"Dari Umar bin Abu Salamah radhiyallahu 'ahuma berkata, 'saat masih kecil, aku pernah berada di bawah pengawasan Rasulullah Saw, Tanganku pernah menjulur ke (arah makanan yang berada di) piring. Maka Rasulullah Saw pun berkata 
kepada ku, 'Hai nak, sebutlah nama Allah. Makanlah dengan (tangan) kananmu, dan makanlah yang ada di dekatmu.” (Ulwan, tt: 420).

Dalam proses mengajarkan pendidikan karakter pada anak didik tentunya tidak bisa secara instan, tetapi melalui proses berkelanjutan. Setidaknya dalam mengajarkan pendidikan karakter anak didik di sekolah misalnya dapat memberikan pengetahuan dan modal pengalaman yang keterkaita dengan peranan dalam kehidupan sosial mereka. Sebagai contoh, di sekolah anak bisa diajarkan untuk selalu disiplin, jujur, tanggung jawab dan tepat waktu dalam proses pembelajaran dan hal-hal tersebut bisa diaplikasikan dalam kehidupan mereka sehari-hari.

Antara pendidikan informal di keluarga/orang tua dan pendidikan formal di sekolah dan idealnya perlu saling bersinergi untuk menumbuhkembangkan karakter anak didik baik di lingkungan sekolah maupun di lingkungan keluarga. Dengan visi dan misi dan program yang bertujuan untuk menciptakan ouput anak didik dengan bekal kemampuan karakter baik, bisa menciptakan generasi yang membanggakan serta berprestasi unggul. Selanjutnya, betapa pentingnya program sekolah dan maddrasah membuat rancangan rencana kegiatan pembelajaran yang dapat menumbuhkan karakter anak didik yang luhur dan terarah. Maka rancangan program dan kegiatan itu jika dilaksanakan dengan keikhlasan dan penuh kesukarelaan dari para guru diharapkan akan terwujudny para insani yang berkarakter disiplin terhadap segala tingkah laku perbuatan dalam kehidupan sehari-hari, inilah karakter pribadi yang harus ditumbuhkembangkan.

Membangun dan mengembangkan potensi karakter anak-anak didik sebagai generasi masa depan bangsa ini menjadi tanggung jawab bersama semua pihak dan komponen bangsa. Perlu keterlibatan kolektif untuk ikut terlibat 'menyingsingkan lengan baju' untuk membangun karakter yang kuat dan khas-islami dalam makna sesungguhnya. Semua elemen dan potensi dalam berbangsa bangsa agaknya perlu bangkit dan bersatu untuk melakukan suatu tindakan dalam membangun karakter bangsa agar negeri ini bangkit dan meraih cita-cita besarnya sehingga mampu sejajar dengan bangsa-bangsa besar dan maju (developed country) lainnya di dunia dan mampu memberikan kontribusi bahkan menjadi pusat beradaban (Saleh, 2012: 10).

Konsekuensinya, berbagai kalangan pelaku lembaga pendidikan dalam beragam jenjang, tingkat dan stratanya--sejak pendidikan dasar, yaitu PAUD, TK, SD, kemudian tingkat yang lebih atasnya SMP, SMA hingga Perguruan Tinggi oleh para pendidik (guru, dosen, staf birokrasi) juga perlu terlibat dalam kesadaran membangun karakter melalui penanaman nilai dan penguatan nilai-nilai karakter itu dengan cara mengajarkannya dan mendidiknya (Saleh, 2012: 12). Hal ini, disebabkan proses belajar memang tidak bisa selesai begitu saja di sekolah. Pihak rumah, keluarga dan orang tua serta masyarakat tidak bisa lepas tangan begitu saja, dan menyerahkan total persoalan belajar anak kepada pihak sekolah. Tetap harus ada kerjasama yang baik antara sekolah 


\section{Sariwandi Syahroni}

Peranan Orang Tua dan Sekolah

dalam Pengembangan Karakter Anak Didik

dan rumah. Harus ada kesinambungan, agar proses belajar di sekolah tidak terputus begitu saja (Istadi, tt: 90).

Sebuah keinginan dan komitmen setiap unsur baik lembaga pemerintah, keluarga/orang tua, masyarakat sedapat mungkin dapat mendukung upaya pengembangan dan penumbuhan pendidikan karakter anak didik. Perlu pula selanjutnya adanya upaya sebuah dan program penumbuhan karakter/ budi pekerti peserta didik dan warga di sekolah dirancang oleh pihak yang memiliki wewenang-terutama pendidik dan orang tua-yang tidak dipungkiri seluruh guru berhak membuat sebuah program penumbuhan karakter/ budi pekerti terhadap anak didik di sekolah. Dan rencana program penumbuhan karakter peserta didik di buat dalam kurun 1 semester, dan 2 semester mempunyai siklus waktu tertentu selama satu tahun ajaran. Setiap satu tahun evaluasi terhadap pengembangan dan penumbuhan karakter anak didik. Perlu dilakukan juga dalam bentuk musyawarah oleh pihak sekolah melibatkan kepala sekolah, guru, komite sekolah, dan masyarakat. Sudah sejauh mana penumbuhan dan pengembangan bibit-bibit pendidikan karakter terhadap peserta didik di sekolah.

Dalam hal ini perlu adanya upaya, peranan, dan strategi penumbuhan dan pengembangan pendidikan karakter bagi sekolah dan orang tua khususnya adapun metode-metode antara lain: Pertama, melalui keteladanan. Karena keteladanan memberikan gambaran secara nyata bagaiman seseorang harus bertindak. Keteladanan berarti kesediaan setiap orang untuk menjadi contoh dan miniatur yang sesungguhnya dari sebuah perilaku. Di dalam Islam, keteladanan bukanlah hanya semata persoalan mempengaruhi orang lain dengan tindakan, melainkan sebuah keharusan untuk melakukan tindakan itu yang berhubungan langsung secara spritual dengan Allah Swt. karenanya, tidak adanya contoh keteladanan akan melibatkan kemurkaan dari Allah Swt sebagaimana Firman-Nya; "Wahai orang-orang yang beriman, kenapakah kamu mengatakan sesuatu yang tidak kamu kerjakan? Amat besar kebencian di sisi Allah bahwa kamu mengatakan apa-apa yang tidak kamu kerjakan. '(Q.S. Ash Shaff, 61:2-3).

Kedua, melalui simulasi praktik (experiential learning). Dalam proses belajar, setiap informasi akan diterima dan diproses melalui beberapa jalur dalam otak dengan tingkat penerimaan yang beragam. Terdapat enam jalur menuju otak, antara lain melalui apa yang dilihat, didengar, dikecap, disentuh, dicium, dan dilakukan; Ketiga, menggunakan metode ikon dan afirmasi (menempel dan menggantung). Memperkenalkan sebuah sikap positif dapat pula dilakukan dengan memprovokasi semua jalur menuju otak kita khususnya dari apa yang kita lihat melalui tulisan atau gambar yang menjelaskan tentang sebuah sikap positif tertentu; Keempat, menggunakan metode repeat power. Yaitu dengan mengucapkan secara berulang-ulang sifat atau nilai positif yang ingin dibangun. Metode ini dapat pula disebut dengan metode dzikir karakter. Metode repeat power adalah salah satu cara untuk mencapai sukses dengan menanamkan sebuah pesan positif pada diri kita secara terus menerus tentang apa yang ingin kita raih; Kelima, metode 99 sifat utama. Metode ini adalah melakukan penguatan 
komitmen nilai-nilai dan sikap positif dengan mendasarkan pada 99 sifat utama (Asma'ul Husna) yaitu pada setiap harinya setiap orang memilih salah satu sifat Allah (Asma'ul Husna) secara bergantian kemudian menuliskan komitmen perilaku apilkatif yang sesuai dengan sifat tersebut yang akan dipraktikkan pada hari itu; Keenam, membangun kesepakatan nilai keunggulan. Baik secara pribadi atau kelembagaan menetapkan sebuah komitmen bersama untuk membangun nilai-nilai positif yang akan menjadi budaya sikap atau budaya kerja yang akan ditampilkan dan menjadi karakter bersama; dan Ketujuh, melalui penggunaan metafora. Yaitu dengan menggunakan metode pengungkapan cerita yang diambil dari kisah-kisah nyata ataupun kisah inspiratif lainnya yang disampaikan secara rutin kepada setiap orang dalam institusi tersebut (siswa, guru, karyawan dll) dan menyampaikan kisah motivasi inspiratif tersebut dapat pula selalu diikutsertakan pada setiap proses pembelajaran atau sesi penyampaian motivasi pagi sebelum memulai pekerjaan (Saleh, 2012: 10-17).

Di sekolah agaknya perlu didorong adanya suatu iklim yang dapat mendorong tumbuhnya proses penumbuhan karakter anak didik. Dalam pelaksanaan penumbuhan karakter atau akhlak yang harus dilakukan adalah memiliki kejelasan pelaksanaan program kurikulum sebagai acuan dalam penumbuhan karakter budi pekerti, mensosialisasikan dan memberikan pemahaman tentang penumbuhan budi pekerti kepada seluruh warga sekolah, Komite Sekolah, orang tua, dan tokoh/sesepuh masyarkat sekitar.

Dalam hal operasional kebijakan pemerintah dalam bidang pendidikan di sekolah/madrasah juga perlu merespon pendidikan karakter di sekolah. Membudayakan 5S (Senyum, Sapa-Salam, Sopan-Santun) dan berakhlak mulia di sekolah adalah wajib diterapkan baik kepada seluruh warga sekolah. Karena karakter memberikan gambaran tentang suatu bangsa, sebagai penanda, penciri sekaligus pembeda suatu bangsa dengan bangsa lainnya. Karakter memberikan arahan tentang bagaimana bangsa ini menapaki dan melewati suatu zaman dan mengantarkannya pada suatu derajat tertentu. Bangsa yang besar adalah bangsa yang memiliki karakter yang mampu membangun sebuah peradaban besar yang kemudian mempengaruhi perkembangan dunia. Maka dari itu perlu ada upaya integrasi pendidikan karakter di setiap mata pelajaran di sekolah. Tidak hanya terdapat pendidikan karakter pada mata pelajaran Pendidikan Agama Islam dan PPKN, semua mata pelajaran bisa mencangkok integrasi pendidikan karakter pada setiap materi pembelajaran. Karena pendidikan sekarang ini lebih menitikberatkan pada aspek kognitif saja dan kurang yang lainnya, hal seperti inilah menyebabkan hilangnya aspek-aspek moral, afektif dan psikomotorik yang dibutuhkan oleh peserta didik.

Selain itu, perlu pula adanya pembiasaan rutinitas di sekolah yang harus dilakukan, yaitu pembinaan wali kelas terhadap peserta didik pada waktu awal jam masuk sekolah selama lima belas menit, bisa dilalukan dengan cara baca al Qur'an dan terjemahannya, budaya literasi dan tausyiah. Jum'at amal dengan cara berinfak dan shadaqah, berbagi sesama. Kegiatan ekstrakurikuler di sekolah, dan kegiatan lomba di 


\section{Sariwandi Syahroni}

Peranan Orang Tua dan Sekolah

dalam Pengembangan Karakter Anak Didik

dalam sekolah, maupun tingkat daerah, nasional hingga internasional. Toleransi dalam perbedaan kenyakinan, menjaga kerukunan antar umat beragama siswa di sekolah. Hasilnya Negara dan Bangsa mempunyai kebangga tersendiri terhadap generasi penerus bangsa yang berkarakter, karena negara Indonesia sudah dikenal oleh negara luar terhadap keramahan, sopan santun, dan gotong royong. Upaya dan strategi atas pelaksanaan program pengembangan pendidikan karakter tersebut, akan berjalan dengan baik apabila ada kesadaran dan dukungan sinergis antara orang tua dan sekolah/madrasah secara konsisten. Inilah tantangan yang diperlukan suatu manajemen sekolah/madrasah yang mampu merespons secara positip atas pentingnya pengembangan pendidikan karakter anak didik sebagai harapan bernilai tinggi terhadap masa depan bangsa.

\section{Kesimpulan}

Suatu proses pengembangan karakter anak didik atau peserta didik memerlukan tanggung jawab kolektif, baik dari orang tua/keluarga maupun sekolah/madrasah. Fondasi dan basis utama (the main basic) memang berawal dari proses pendidikan pada orang tua/ keluarga. Tetapi, mengingat adanya keterbatasan orang tua di keluarga dalam mengembangkan potensi bakat, minat, dan cita-cita masa depan anak-anak maka selanjutnya tanggung jawab itu berbagi dengan lembaga pendidikan formal di sekolah. Idealnya, orang tua telah meletakkan basis pendidikan karakter, akhlakul karimah, pada anak didik dengan kuat di keluarga. Sekolah (guru, staf-karyawan) dalam sistem dan budaya sekolah yang mumpuni selanjutnya dapat meneruskan pendidikan karakter dengan baik dan wajar seperti diharapkan orangtua dan masyarakat dimana mereka akan berkiprah nantinya.

Akan tetapi, dalam perkembangannya, pihak sekolah daan madrasah sering kali dihadapkan suatu kenyataan yang berbeda, antara cita-cita, obsesi, dan keinginan umumnya. Orang tua (keluarga) dan guru (sekolah) tentunya mengharapkan anak didik menjadi suatu kepribadian yang tangguh dan unggul dari berbagai potensi sebagai insan mulia yang berakhlak mulia, dan bukannya sebaliknya berkepribadian yang buruk maka disebut akhlak tercela. Mengingat, suatu kepribadian seseorang anak didik akan berkembang tidak langsung secara pasif, tetapi secara aktif, dan dinamis untuk mempergunakan kapasitasnya untuk menyesuaikan diri dengan lingkungan sosial, disinilah agaknya peluang atas perlunya upaya dan peranan kolektif dalam proses pengembangan atau pembangunan karakter anak didik sangat mungkin dapat dilakukan, yakni sinergitas peranan orang tua dan sekolah/madrasah. Lebih dari itu, perlu adanya kesadaran dari semua elemen bangsa lainnya, terlebih pemerintah, atas perlunya kesadaran dan kebijakan membangun karakter bangsa yang akseleratif dalam menumbuh generasi berkarakter yang diharapkan dapat membawa kemajuan bangsa yang berkempetitif dengan bangsa maju lainnya, dengan tetap memiliki jati diri bangsa. 


\section{Daftar Pustaka}

Al Bahi, Muhammad. 2014. Kebangkitan Islam di Bawah Bayang-bayang Mendung. Jakarta: Pustaka Alhusna.

Azizy, A. Qodri. 2004. Pengembangan Ilmu-ilmu Keislaman. Semarang: Aneka Ilmu.

Direktorat Jenderal Pendidikan Dasar dan Menengah, Kemdikbud Tahun 2016

Idi, Abdullah \& Safarina. 2016. Etika Pendidikan Keluarga, Sekolah dan Masyarakat. Edisi Baru. Jakarta: PT Rajagrafindo Persana.

Idi, Abdullah. 2015. Dinamika Sosiologis Indonesia. Yogyakarta: PT LKiS Printing Cemerlang.

Idi, Abdullah. 2016. Sosiologi Pendidikan Keluarga, Sekolah dan Masyarakat. Editor: Safarina Hd. Edisi Ke-5. Jakarta: PT Rajagrafindo Persada.

Istadi, Irawati. 2005. Agar Anak Asyik Belajar. Jakarta: Pustaka Inti.

Mardalis. 2007. Metode Penelitian Suatu Pendekatan Proposal. Jakarta : Bumi Aksara.

Prolog. "Pendidikan Karakter, Kumpulan Pengalaman Inspiratif” Milik Negara.

Qurtuby, Usman el. 2014. Al Qur'anulkarim Terjemahan \& Tajwid Berwarna, Bandung: Cordoba.

Ramayulis. 2008. Ilmu Pendidikan Islam. Jakarta: Kalam Mulia.

Saleh, Muwafik. 2014. Membangun Karakter dengan Hati Nurani (Pendidikan Karakter untuk Generasi Bangsa). Jakarta: Erlangga.

Santrock, John W. Tanpa Tahun. Remaja (edisi kesebelas). Jakarta: Erlangga.

Ulwan, Abdullah Nasih. 2006. Ensiklopedia Pendidikan Akhlak Mulia, Panduan Mendidik Anak Menurut Islam. Jakarta: PT Lentera Abadi.

Zaprulkhan. 2013. Kisah-kisah Sufistik Membingkai Makna Hidup Melalui Kisah-kisah Sufistik. Yogyakarta: CV. Idea Sejahtera. 
Sariwandi Syahroni

Peranan Orang Tua dan Sekolah

dalam Pengembangan Karakter Anak Didik

Intelektualita: Volume 06, Nomor 01, 2017 Available Online at: http://jurnal.radenfatah.ac.id/index.php/intelektualita 